\title{
Object Exchange
}

Katherine Knight

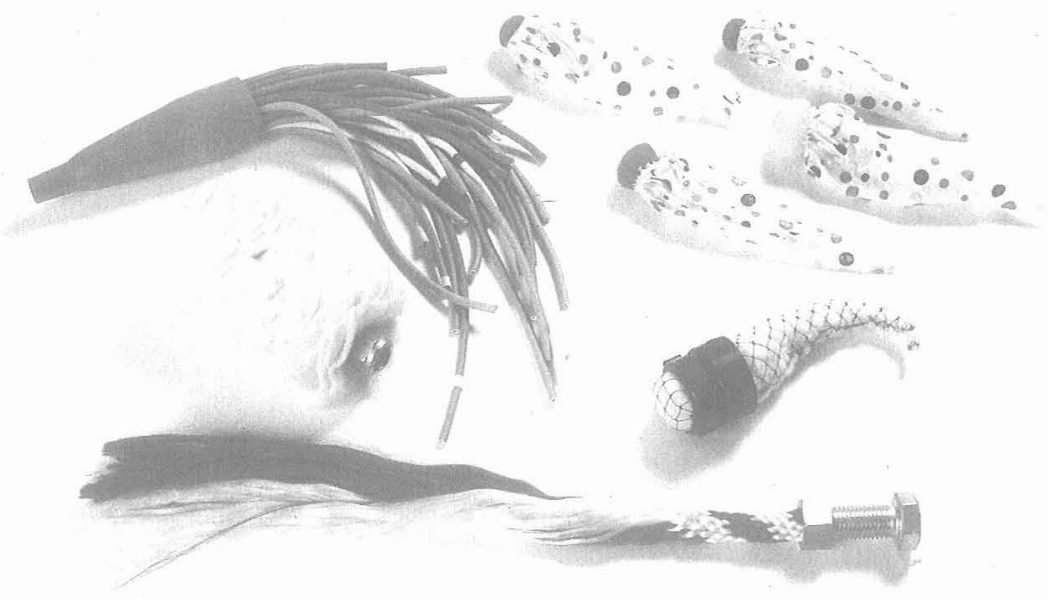


Object Exchange 109

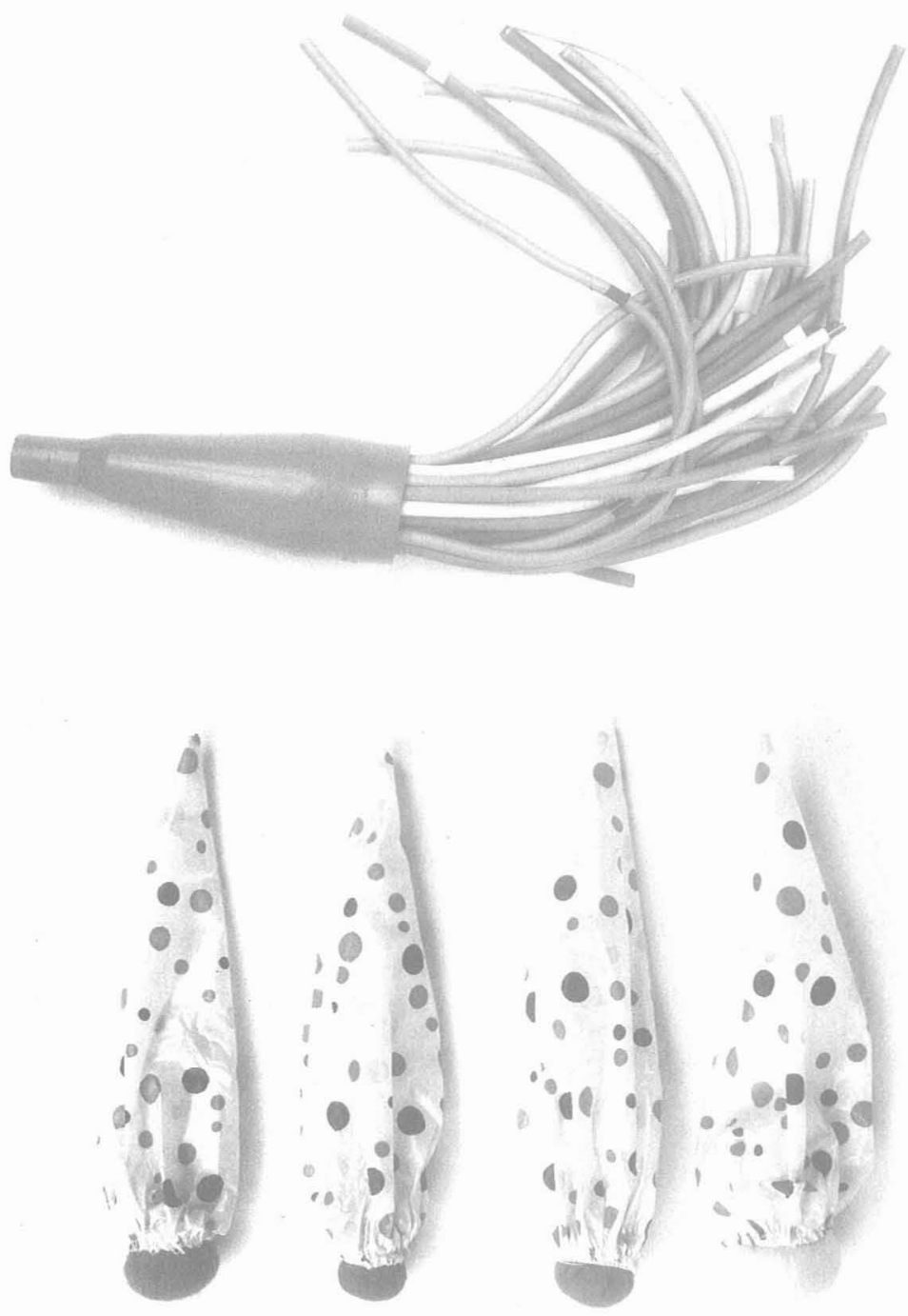

